\title{
Quo Vadis Ultimum Remedium in Tax Criminal Crimes In Indonesia
}

\author{
Lucky Kartanto, ", Prasetijo Rijadi **, Sri Priyati *** \\ * Lecturer at Accounting Programs, at Faculty of Economics And Business, Widya Kartika University, Surabaya, East Java, Indonesia \\ ** Lecturer at Undergradutae and Master Programs, at Faculty of Law, Bhayangkara University, Surabaya, East Java, Indonesia \\ *** Lecturer at Undergradutae Programs, at Faculty of Law, Bhayangkara University, Surabaya, East Java, Indonesia
}

DOI: $10.29322 /$ IJSRP.10.03.2020.p9902

http://dx.doi.org/10.29322/IJSRP.10.03.2020.p9902

\begin{abstract}
Tax Revenue is a mandatory contribution that is paid by the people to the state without direct contradiction and will be used for the benefit of the government and the general public Mardiasmo (2011). According to Siti Resmi (2013) tax has two important functions in a country's economy. First, taxes are a source of government funding for development, both the central and regional governments. Both taxes function as tools that govern government policies in the socio-economic field. Tax revenue has increased significantly both in nominal and percentage amounts to total state revenue. On the other hand the percentage of taxpayers is still very small when compared to the total population in Indonesia. This shows the awareness of the people of Indonesia to pay taxes is still low. The responsibility for tax payment obligations, as a reflection of the legal obligations in the field of taxation, rests with the community members themselves to fulfill these obligations. This is in accordance with the self assessment system adopted by the Indonesian Taxation System. The government, in this case the Directorate General of Taxes, in accordance with its function is obliged to conduct guidance / counseling, service, and supervision. In carrying out these functions, the Directorate General of Taxation tries its best to provide services to the public in accordance with the vision and mission of the Directorate General of Taxes. Ultimum Remedium is one of the principles contained in Indonesian criminal law which says that criminal law should be made a final effort in the case of law enforcement. This has meaning if a matter can be resolved through other lines (family, negotiation, mediation, civil, or administrative law) should the passage be passed. Tax Criminal Law Arrangement based on Law Number 28 Year 2007 regarding General Provisions and Tax Procedures along with the Implementing Regulations. These Regulations have been in place since 2008 so there is a need for changes, especially related to the era of Information technology in Business transactions The application of Ultimum Remedium in Taxation Crimes in Indonesia does not provide a legal certainty for taxpayers, because the regulation instrument has uncertainty in its application whether to use the Ultimum Remedium Principle or Premum Remedium, this is because the Directorate General of tax has a very broad authority related to granting Criminal sanctions or administrative sanctions.
\end{abstract}

Index Terms- Tax Payer, Self Assessment, Tax Criminal, Ultimum Remedium

\section{INTRODUCTION}

Tax Revenue is a mandatory contribution that is paid by the people to the state without direct contradiction and will be used for the benefit of the government and the general public Mardiasmo (2011). According to Siti Resmi (2013) tax has two important functions in a country's economy. First, taxes are a source of government funding for development, both the central and regional governments. Both taxes function as tools that govern government policies in the socio-economic field. Tax revenue has increased significantly both in nominal and percentage amounts to total state revenue. On the other hand the percentage of taxpayers is still very small when compared to the total population in Indonesia. This shows the awareness of the people of Indonesia to pay taxes is still low.

According to Widayati and Nurlis who in the research of Ramadiansyah, Sudjana, \& Dwiatmanto (2014) outline several forms of taxpaying awareness that encourage taxpayers to pay taxes, one of which is the awareness that taxation is a form of participation in supporting state development. Public understanding of tax regulations is very important, it will encourage public awareness, especially taxpayers to fulfill their tax obligations. This is in line with the results of research by Masruroh Siti \& Zulaikha (2013) which states that the knowledge and understanding of tax regulations is the process of taxpayers knowing and applying that knowledge to pay taxes.

Tax has a very important role in the life of the state, especially in the implementation of development because the tax is a source of state revenue to finance all expenses including development expenses. On the other hand taxes are also very important in 
regulating economic growth through tax policy. On the other hand taxes have a very important role in the life of the state, taxes have several functions, including:

1. Budget function, which is a tax used as a tool for optimally entering funds into the state treasury based on applicable tax laws, so that the tax functions to finance all expenses related to government processes. The tax is used for routine financing, such as: employee expenditure, goods expenditure, maintenance, and others. For development financing, money is spent on government savings, i.e. domestic revenues minus routine expenses. The government savings are continually increased from year to year according to the increasing development financing needs.

2. Regulatory Functions, i.e., taxes are used by the government as a tool to achieve certain goals and are complementary to the budget function. The government can regulate economic growth through tax policies. For example: in the context of investment, both domestically and abroad, various tax relief facilities are provided. In order to protect domestic production, the government sets high import duties on foreign products.

3. Stability Function, which is a tax that makes the government have funds to carry out policies related to price stability, so that inflation can be controlled. This can be done by regulating the circulation of money in the community, tax collection, and effective and efficient use of taxes.

4. Income Retribution Function, which is a tax used to finance all public interests. Including to finance development so as to open job opportunities, so as to increase community income. Taxes are the main source of state revenue. Without taxes, most state activities are difficult to implement. The use of tax money covers everything from personnel expenditure to financing various development projects. Construction of public facilities such as roads, bridges, schools, hospitals, police stations is funded using tax money. Tax money is also used for financing in order to provide security for all levels of society. Every citizen from the moment of birth until death, enjoys the facilities or services of the government which are all funded with money from taxes. Thus it is clear that the role of tax revenue for a country becomes very dominant in supporting the running of government and development financing.

The responsibility for tax payment obligations, as a reflection of the legal obligations in the field of taxation, rests with the community members themselves to fulfill these obligations. This is in accordance with the self assessment system adopted by the Indonesian Taxation System. The government, in this case the Directorate General of Taxes, in accordance with its function is obliged to conduct guidance / counseling, service, and supervision. In carrying out these functions, the Directorate General of Taxation tries its best to provide services to the public in accordance with the vision and mission of the Directorate General of Taxes.

One of the strategies used by the Directorate General of Taxes to Increase Tax Compliance and Receipt is by Law Enforcement. Enforcement of tax law means as a step how to enforce the legal norms contained in the Tax Law. Law on General Provisions and Tax Procedures Number 6/1983 (UU KUP) states that law enforcement can be done in two ways, namely, the administrative or criminal way. Enforcement of tax law means as a step how to enforce the legal norms contained in the Tax Law. Namely General Provisions and Taxation Procedures Number 28 Year 2007 As Last Amended With Law Number 16 Year 2009 (UU KUP) states that law enforcement can be done in two ways namely, administrative or criminal ways.

In Tax Crime there is a legal principle known as "Ultimum Remedium" which makes criminal sanctions the last resort of a series of stages of law enforcement, which is a general principle inherent in the formal legal system of taxation throughout the world, both in countries adhering to continental and Anglo- European legal systems. Saxon. This can be understood, because unlike the Antiterrorism Law or the Anti-Corruption Law which applies the principle of "Primum Remedium" the tax system is intended to collect state revenue, not to punish terrorists or corruptors. From this purpose the application of the principle of ultimum remedium has its justification and legitimacy.

According to Sudikno Mertokusumo (2006:128) it implies that Ultimum Remedium as the last tool in law enforcement that ultimum Remedium is not only a term, but also a legal principle. According to Sudikno Mertokusumo (2006:7), among others, he said that the principle of law is abstract. Because of its nature, the principle of the law in general is not not poured in the form of concrete rules or articles, such as:

1. Point D'interet Point d'action (who has a legal interest can file a lawsuit);

2. Restitutio in integrum (return to its original state);

3. In Dubio pro reo (in the case of doubt the judge must decide so to benefit the defendant);

4. Res judicata Pro veritate Habetur (what the judges are disconnected should be considered correct);

5. Everyone is deemed to know the law;

6. Protection against good-faith third parties.

Ultimum Remedium is one of the principles contained in Indonesian criminal law which says that criminal law should be made a final effort in the case of law enforcement. This has meaning if a matter can be resolved through other lines (family, negotiation, mediation, civil, or administrative law) should the passage be passed.

The term Ultimum Remedium according to Wirjono Prodjodikoro (2003:17) says that norms or conventions in the field of constitutional law and State administrative law must first be addressed by administrative sanctions, as well as norms In the field of civil law must first be addressed by civil sanction. Only, if the administrative sanction and the civil sanction is not sufficient to achieve the goal of the public balance sheet straightening, then only a criminal sanction as the ultimate (last) or Ultimum Remedium. According to Wirjono (2003:50) says that the nature of criminal sanctions as the ultimate weapon or Ultimum Remedium when compared with civil sanction or administrative sanction. This trait has caused a tendency to save in criminal sanctions. So, from here we know that the Ultimum Remedium is a term that describes a nature of criminal sanctions. 
In addition to being known in criminal law, the term is also known in the law of dispute resolution, that conventionally, the settlement of disputes in the business world, such as in trade, banking, mining projects, oil and gas, energy, Infrastructure, and so on is usually done through litigation. In the litigation process placing the parties opposite each other, in addition to litigation dispute resolution is the final means (Ultimum Remidium) after another dispute resolution alternative does not yield results.

With the description in the background above, there are 2 (two) problems which consist of:

1. How the Legal Regulations Related to Tax Criminal law in Indonesia?

2. Is in a tax criminal act applied Ultimum Remedium principle?

\section{LITERRATURE REVIEW}

\section{Legal State Theory \\ a. Indonesian State Law Theory}

Article 1 paragraph (3) of the 1945 Constitution and Article 4 letter a of Law Number 37 Year 2008 About the Ombudsman of the Republic of Indonesia stipulates that Indonesia is a legal state. The rule of law is a state which in all aspects of life, society, nation and state including in the administration of government must be based on law and general principles of good governance and aims to improve democratic life that is prosperous, just and responsible. According to Sri Sumantri in Hufron, the elements of the state of Pancasila law are: (1) There is recognition of human rights guarantees and citizens; (2) There is a division of power; (3) Implementation of duties and obligations of the government must always be based on applicable law, both written and unwritten; (4) The existence of an independent judicial power, meaning that it is independent of the influence of government power.

In line with this opinion, Padmo Wahyono in Muhammad Tahir Azhary (2004: 94-99) cited by Hufron stated about the theory of the state of Pancasila law, namely: 1) The root of the family principle stated in the 1945 Constitution; 2) The family principle prioritizes: "the people are many, but human dignity and values are still respected"; 3) Understanding the state and legal understanding seen from the principle of family are: a) The Indonesian state was formed not because of "community agreement" from "naturalist status to civil status with protection of civil rights, but" thanks to Allah Almighty with the noble desire to free national life; b) There are three functions of law that are safeguarding from a family principle, namely: - Upholding democracy in accordance with the system of government of the country contained in the 1945 Constitution; - Realizing social justice in accordance with Article 33 of the 1945 Constitution; - Uphold humanity based on the One Godhead in a Just and Civilized manner. (Hufron 2012: 48-49).

The legal state of the Republic of Indonesia is a country with a conscience or a country that has concern. The legal state of Indonesia is not a country which only stops its duty to carry out various public functions, not the State "by job description", but a country that wants to realize the moral contained in it. Indonesia's legal state is more of a "moral design" state. Therefore, running a state of law in Indonesia is to carry out state activities that have a conscience, so that every actor in a state position is obliged to find out what concerns the State (the conscience of the state) are attached to the tasks and work carried out. Concern is the essence of work that animates the implementation of the work, namely compassion, empathy, dedication, commitment, honesty and courage. The results of work are not only measured in terms of quantity, but also quality, because they are based on "moral description". With that guideline and enthusiasm, the Indonesian legal state will truly become Indonesia (Satjipto Rahardjo, 2009: .93).Indonesia is a legal state which in all aspects of life, community, nation and state including in the administration of government must be based on law and general principles of good governance and aims to improve democratic life that is prosperous, just and responsible.

\section{b. Rechtstaat Law's Theory of State}

According to S F.Marbun in Hasan Zaini (1974: 154,155), one expert who was quite instrumental in expressing the concept of the rule of law was F.J. Stahl, a scholar from Germany. According to Sthal: "The state must be a legal state that is the driving force of the development of the times. The state must determine carefully the streets and the boundaries of its activities as well as the environment (atmosphere) that can not be penetrated. The state must realize or impose moral ideas in terms of the state according to the existing legal atmosphere ". (SF.Marbun 2001: 7) According to Freidrich Julius Stahl as quoted by Donald A. Rumokoy in Kuntjoro Purbopranoto (1969: 18) in Continental European countries, the rule of law contains elements: (1) The existence of protection of human rights (grondrechten); (2) The sharing of power ( scheiding van machten); (3) The government must be based on legal regulations (wetmatigheid van bestuur); (4) The existence of an administrative court (administrative recommendations).

\section{c. State Law Rule of Law Theory}

In Anglo-Saxion countries a concept of legal state developed which was originally pioneered by A.V. Dicey from England, as the rule of law, in his book Introduction to the Law of the Constitution was quoted as saying by Mariam Budiardjo. According to A.V. Dicey the concept of the rule of law contains three elements, namely: (1) Supremacy of the rule of law (supremacy of law), absence of arbitrary power, in the sense that someone can only be punished if violating the law; (2) The same position in the face of law (equality before the law), this argument applies both to ordinary people and officials; (3). Guaranteed human rights by law (in other countries by the constitution) and court decisions. (Soetanto Soepiadhy, 2012)

\section{Norma Level Theory (Stufenbau Des Theory Recht)}

Norms are a measure that must be obeyed by a person in relation to others or with the environment, the term norm comes from Latin, or rules in Arabic, and is often also referred to as guidelines, standards, or rules in Indonesian. In its development the norm is interpreted as a measure or benchmark for someone to act or behave in society. So, the core of a norm is all rules that must be 
obeyed. (Maria Farida 2006: 6) According to Hans Kelsen, legal norms are rules, patterns or standards that need to be followed. Then explained further that the function of legal norms is:

a) Governing.

b) Prohibit.

c) Authorize.

d) Allow.

e) Deviating

from the provisions (Yuliandri, 2010.:21) In specifying the discussion or discussion of legal norms or norms, it is necessary to understand more deeply the theory of "stufenbau" from Kelsen. According to Kelsen, then the rule of law of a country, is a system of hierarchical legal rules which in its very simple form. (Purnadi Purbacaraka, 1979.:41 According to Adolf Merkl, a legal norm upward is sourced and becomes a source for the legal norms below it so that a legal norm has a validity period (rechtskracht), therefore the validity period of a legal norm depends on the legal norms above it so that if the legal norms above are revoked or deleted, then the legal norms under them are revoked and deleted as well. Based on Adolf Merkl's theory, in the norm level theory, Hans Kelsen also put forward his theory regarding the level of legal norms (stufentheori), where he argues that legal norms are tiered and layered in a hierarchy of arrangements, where a lower norm applies, sourced, and based on higher norms, higher norms apply, sourced and based on higher norms, and so on come to a norm that cannot be traced further and is hypothetical and fictitious. So the basic rules above are often called "grundnorm" or "ursprungnorm".

According to Kelsen, grundnorms are generally meta juridisch, not the product of the legislative body (de wetgeving), not part of the laws and regulations, but are the source of all sources of the legislative order below. The basic norms which are the highest norms in the norm system are no longer formed by a higher norm, but the basic norms are determined first by the community as the basic norm which is a hanger for the norms that are below it so that a basic norm is said pre-supposed. (Maria Farida Indrati Soeprapto 2010.:4) Based on the explanation, it is known that the legal norms in a country according to Hans Kelsen are as follows: 1) A rule of law is a hierarchical system of legal rules.

2) The simplified structure of the rule of law from the lowest level up.

3) The validity of the legal rules of the lower level group depends or is determined by the rules which belong to the higher level.

Furthermore, in the viewpoint of establishing legal norms, Benjamin Akzin argues that the formation of public law norms is different from the formation of norms of private law because if we look at the norm structure, then public law is above private law, whereas when viewed from an institutional structure, Public Authoritis is located on the population. In terms of its formation, public legal norms are formed by state institutions (state authorities, people's representatives) or also called infrastructure so that in this case it is clear that the legal norms created by these state institutions have a position that higher than legal norms formed by the community or also called infrastructure.

Because public legal norms are formed by state institutions, the actual formation must be carried out carefully, because these public legal norms must be able to fulfill the wishes and desires of the people, so that the norms of private law are different. The norms of private law are usually always in accordance with the wishes / desires of the people because this private law is formed by the community concerned with agreements or transactions that are civil in nature so that the community can feel for themselves whether the legal norms are appropriate or not with the will or people's wishes. Hans Nawiasky argues that in addition to the norms are multilayered and tiered, legal norms of a country are also groups. Hans Nawiasky classifies legal norms in a country into four major groups consisting of: (1) Group I, Staatfundamentalnorm (fundamental norms of the state). (2) Group II, Staatgrundgesetz (state basic rules). (3) Group III, Formell Gezetz (formal law). (4) Group IV, Verodnung \& Autonome Satzung (implementing rules \& autonomous rules) These groups of legal norms almost always exist in the arrangement of legal norms of every citizen even though they have different terms or the number of legal norms that are different in each group. The highest legal norm is the first group is staatsfundamentalnorm. The term staatsfundamentalnorm was translated by Notonagoro in his speech at the first Anniversary of Airlangga University (November 10, 1955) with "fundamental principles of the state", then by Joeniarto, in his book entitled the history of constitutional republic of Indonesia, called the "first norm", fundamental norms the country which is the highest norm in a country is a norm that is not formed by a higher norm, but is determined in advance by the community in a country and is a norm that becomes the place of dependence on legal norms below it. It is said that the highest norms are not formed by higher norms because if the highest norms are formed by even higher norms, it is not the highest norm. Staatsfundamentalnorm of a country is a basic foundation of philosophy that contains basic rules for further state regulation. According to Hans Nawiasky, the term staatsfundamentalnorm is a norm that is the basis for the formation of a constitution or constitution of a country (staatsverfassung), including the norm of its modification. The legal nature of a staatsfundamentalnorm is a condition for the enactment of a constitution or constitution. He existed before the constitution or constitution. According to Carl Schmitt, the constitution is a joint decision or consensus about the nature and form of a political unity (e-artifactscheidung uber art und form einer politischen einheit), agreed upon by a country.

\section{Legal Purpose Theory}

A. Justice

By Aristotle justice is generally divided into 3

1. Legal Justice (Iustitia Legalis):

The definition of legal justice is justice according to the law where the object is a society protected by the law for the common good or banum commune. Justice means being one-sided, putting things in the middle, impartial, siding with the right, not 
arbitrary. Justice also has another meaning, namely a state of life for the people, the nation and the state to get what is their right so that they can carry out their obligations.

\section{Commutative Justice}

This commutative justice is a treatment for someone without seeing the services that have been given. This justice regulates fair relations between one person and another or between one citizen and another citizen. Commutative justice concerns horizontal relations between citizens and other citizens. business, commutative justice is also called or applies as exchange justice. In other words, commutative justice involves fair exchange between the parties involved.

3. Distributive Justice

The basic principle of distributive justice known as economic justice is equitable economic distribution or that is considered fair for all citizens. Distributive justice has relevance in the business world, especially companies. Based on the principle of justice in Aristotle's style, each employee must be paid according to the achievements, duties, and responsibilities given to him. According to Lon Fuller, the book "The Morality Of Law" is thoroughly familiar: law. That is (the only formula that can be called the legal definition offered by these writings is "now it is true- really familiar: law is a company of subduing human behavior with rules. Unlike most modern theories of law, this view treats law as an activity and regards the legal system as a product of continuous purposive efficiency).

\section{B. Certainty Normative legal}

certainty is when a regulation is made and promulgated with certainty because it regulates clearly and logically. Obviously the meaning does not cause doubt (multi-interpretation) and logically means that it becomes a norm system with other norms so that it does not clash or cause norm conflicts. According to Hans Kelsen, law is a system of norms. Norms are statements that emphasize the "supposed" aspect or das sollen, by including some rules about what to do. Norms are products and deliberative human actions. The law which contains general rules becomes a guideline for individuals behaving in a society, both relationships with fellow individuals and their relationship with the community. These rules become a limitation for the public to burden or take action against individuals. The existence of these rules and the implementation of these rules lead to legal certainty. Legal certainty will be achieved if the law is as much as possible. the law contained contradictory provisions (laws based on a logical and practical system). The law was made based on the reconciliation agreement (a serious legal situation) and the law contained no terms that could be interpreted in different ways. Lon Fuller, his book, the Morality of Law, proposes 8 (eight) principles that must be met by law, which if not fulfilled, the law will fail to be called a law, or in other words there must be legal certainty. The eight principles are as follows:

1. A legal system consisting of regulations, not based on misguided decisions for certain matters;

2. The regulation is announced to the public;

3 . Not retroactive, because it will damage the integrity of the system;

4. Formulations that are understood by the public are made;

5. There must be no conflicting rules;

6. It may not require an action that exceeds what can be done;

7. May not be changed frequently;

8. There must be conformity between regulations and daily implementation. The opinion of Lon Fuller above can be said that there must be certainty between the rules and their implementation, thus entering the realm of action, behavior and factors that influence how positive law is implemented.

\section{Benefits}

Etymologically, the word "usefulness" comes from the basic word "benefit", which according to the Indonesian Language Dictionary, means useful or useful. Law is the lifeblood of a nation to achieve the ideals of a just and prosperous society. For Hans Kelsen the law itself is a sollens category (category of necessity) rather than synonymy (factual category). What that means is that the law is constructed as a necessity that regulates human behavior as a rational being. This issue which is questioned by law is not 'how the law should be' (what the law ought to be) but 'what is the law' (what is the law). Some people argue that the utility of law (utility) is highly correlated with the purpose of predatory punishment. specifically so that the defendant does not repeat the act against the law, and the general prevention of everyone being careful not to violate the law because they will be subject to sanctions. Therefore the judge's decision must benefit the world of justice, the general public and the development of science. This research tries to link the Utilitarianism flow of Rudolf von Jhering known as the originator of the theory of Social Utilitarianism or Interessen Jurisprudence (interest). The theory is a combination between Bentham and Stuar Mill's theory and legal positivism from John Austin. The focus of Jhering's legal philosophy is about purpose, as his book states that the goal is the creator of all laws, there is no legal rule that does not have its origin in this purpose, that is, in practical motives. Furthermore according to Jhering, my position in the world rests on three propositions: First, I am here for myself, Second, the world is for me, and Third, I am here for the world without harming me. Then Jhering introduced the objective suitability theory as an answer to the interests of individual social life. Conformity of objectives or more precisely adjusting these objectives is the result of uniting interests for the same purpose namely benefit. So that the law functions in addition to guaranteeing the freedom of individuals to achieve their goals, namely pursuing benefits and avoiding losses, the law is also tasked with organizing individual goals and interests so that they are related to the interests of others. According to Jhering, there are four interests of the people who are the targets of the law which are selfish, which are rewards and benefits which are usually dominated by economic motives. Whereas moralistic ones are obligation and love. Law is in charge of arranging in a balanced and harmonious manner between these interests.

\section{Authority Theory}


Large Indonesian Language Dictionary (KBBI), the word "authority" means: Rights and power to act; authority, Power makes decisions, rules and delegates responsibility to others. Functions that may be carried out. Whereas "authority" means: a. Thing authorized,

b. Rights and powers that have to do something. In addition, the KBBI power has the meaning:
a. Power (to take care, govern, etc.),
b. Ability; ability,
c. Areas (places etc.) that are controlled,
d. The ability of people or groups, to control other people or groups based on authority, authority, charisma, or physical power
e. The function of creating and strengthening peace, justice and preventing and acting against injustice or injustice.

Formally, the authority of the government to regulate the land sector comes from Article 33 paragraph (3) of the 1945 Constitution of the Republic of Indonesia which states that the earth and water and natural resources contained therein are controlled by the state and are used for the greatest prosperity of the people. Then solidly realized UUPA. Authority or authority is a term commonly used in the field of public law. But actually there is a difference between the two. Authority is what is called "formal power", power that comes from powers granted by the Act or the legislature from executive or administrative powers. Therefore, it is the power of a certain group of people or power over a sector of government or a certain government affairs. While the authority is only about a certain part of the authority. Authority is the right to give orders, and the power to ask is obeyed. 2. Types of Authority Every act of government must rest on a legitimate authority. Without legal authority, an official or institution cannot carry out a government action. Therefore, legitimate authority is an attribute for every official or institution. Based on the source, the authority is divided into two namely personal authority and official authority. a. Contributions Attribution is the authority attached to a position. review of constitutional law, this attribution is shown the authority possessed by government organs to run their government based on the authority established by the legislators. This attribution refers to the original authority on the basis of the constitution (Constitution) or legislation. $b$. Abundance of authority Delegation of authority is the surrender of part of the authority of the superior officer to the subordinate helping to carry out the duties of his duty to act alone. Delegation of this authority is intended to support the smooth running of the task and order the flow of communication that is responsible, and insofar as it is not specifically determined by applicable laws and regulations.

In addition to attribution, authority can also be obtained through a delegation process called: Delegation, namely Delegation is given usually between government organs one with another government organ, and usually the authorizing party has a higher position than the party given the authority. Whereas the Mandate is given an internal working relationship between superiors and subordinates. Lutfi Effendi's book, legitimate authority if it is reviewed from where the authority was obtained, then there are three categories of authority, namely attributive, mandate, and delegation.

a. Attributive Authority

Attributive authority is usually outlined or derived from the division of state power by the Constitution. Another term for attribute is authentic authority or authority that cannot be shared with anyone. attributive authority, the implementation is carried out by the official or the body itself, the basic regulations are stated. As for responsibility and accountability are with officials or the body as stated in the basic regulations.

b. Mandate Authority

The authority of the mandate is the authority that comes from the process or procedure of delegation from a higher official or body to an official or lower body. The authority of the mandate is that there is a routine relationship between subordinate superiors, unless explicitly prohibited. Then, at any time the author can use the delegated authority himself.

c. Delegative authority

Delegative authority is the authority that comes from delegating a government organ to other organs on the basis of legislation. In contrast to the mandate authority, delegative authority, responsibility and accountability turn to those who are given the abundance of authority or turn to delegataris. In this way, the giver of authority is not able to use that authority again except after the revocation is held by adhering to the principle of contrarius actus. Therefore, the delegative authority of the basic regulations in the form of legislation is the basis for the birth of the delegative authority. Without the legislation that regulates the delegation of authority, there is no delegative authority. Meanwhile, according to Philipus M. Hadjon, "The authority to make decisions can only be obtained in two ways, namely by attribution or by delegation. Attribution is the authority inherent in a position "(Philipus M. Hadjon, 2001: 130) Philipus added that "Speaking of delegations there is a transfer / transfer of an existing authority. If the authority is not perfect, it means that a decision based on that authority is not lawful. " Delegation is the surrender of authority that belongs to the organ of government to other organs. The delegation contains a submission, that is, what was originally the authority of one party, which subsequently became the authority of the second party. The authority given by the delegate is then the responsibility of the authority. The mandate, there does not occur a new authorization or delegation of authority and Agency or TUN Officials to one another. The responsibility of authority on the basis of the mandate remains with the creditor, does not change to the recipient of the mandate. F.A., M. Stroink and J.G. Steenbeek, as quoted by Ridwan HR, argued that two ways government organs obtain authority, namely: attribution; and delegation. As a legal system, authority consists of at least three components, namely: influence; legal basis; and legal conformity. The component of influence is that the use of authority is intended to control the behavior of legal subjects. The basic legal component is that the authority must always be able to be appointed by its legal basis and the component of legal conformity 
implies the existence of authority standards, namely general standards (all types of authority) and special standards (for certain types of authority).

\section{DISCUSSION}

A. REGULATION OF TAXATION CRIMINAL LAW Legal Regulations Related to Tax Crimes can be described as follows:

1. Legal Basis

1. Law number 28 year 2007 on the third amendment to Law No. 6 of 1983 on general provisions and taxation procedures (KUP)

2. ACT number 16 of year 2009 concerning the determination of the government regulation of the Substitute Law number 5 year 2008 on the Fourth Amendment to Law No. 6 of 1983 concerning general provisions and taxation procedures of law

3. Regulation of the Minister of Finance No. 239/PMK. 03/2014 On procedures for evidence of preliminary proof of criminal offence in taxation

4. Regulation of the Director general of taxation number PER-3/PJ/2011 On procedures for implementing development and analysis of information, Data, reports, and complaints through observation or taxation intelligence activities

5. Regulation of the Director general of taxation number PER-19/PJ/2013 on revocation of some regulation of the Director General of taxation relating to the issuance of regulation of the Minister of Finance in the field of general provisions and taxation procedures

6. Regulation of the Director general of taxation number PER-04/PJ/2014 on the decision revocation of the Director general of tax KEP-272/PJ/2002 regarding instructions on observation implementation, preliminary proof examination, and criminal investigation in the field of taxation

7. Regulation of the Director general of taxation number PER-18/PJ/2014 On instructions for implementation of information development and analysis, Data, reports, and complaints

8. Circular Letter of the Directorate General of tax Number SE-23/PJ/2015 on Technical Instructions for evidence of preliminary crimes in taxation

2. Types of sanctions

1. (Article 38 Act No. 28 year 2007)

Violation of the tax obligations conducted by the taxpayer, as long as the action of taxation administration, is subject to administrative sanctions by issuing a tax assessment letter or tax bill, while those concerning criminal acts in the taxation field are subject to criminal sanctions.

2. Offences involving tax crimes

(Article 38 Act No. 28 year 2007)

Violations involving taxation crimes, among others, because:

1. Idolatry; Or

2.Intentional

In addition, criminal sanctions may also be imposed against officials or third parties who commit acts involving criminal acts in the taxation field as referred to in the KUP .

3. $\quad$ Sanctions for Negligence (Article 13A jo. Article 38 of Law Number 28 Year 2007)

Taxpayers are declared to have neglected, if the Taxpayer:

a. do not submit SPT; or

b. submit SPT, but the contents are incorrect or incomplete, or attach information that is incorrect so that it can cause losses to state revenues. If the negligence is done for the first time by the Taxpayer, the Taxpayer will not be subject to criminal sanctions but will be subject to administrative sanctions in the form of an increase of $200 \%$ (two hundred percent) of the amount of underpaid tax determined through the issuance of the Underpayment Tax Assessment Letter (SKPKB). However, if the WP is declared to repeat or commit negligence as referred to above, the sanctions that arise are:

a. sanction of fines, at least 1 (one) time the amount of tax owed that is not or not fully paid and at the most 2 (two) times the amount of tax payable that is not or underpaid, or

b. sentenced to confinement for a minimum of 3 (three) months or a maximum of 1 (one) year. Negligence referred to in this article means that it is not intentional, negligent, careless, or does not heed its obligations so that the act can cause a loss in state income.

4. $\quad$ Sanctions for Intentions (Article 39 paragraph (1) of Law Number 28 Year 2007)

Taxpayers are declared intentional, if the Taxpayer intentionally:

a. did not register themselves to be given a Taxpayer Identification Number or did not report their business to be confirmed as a Taxable Entrepreneur;

b. misuse or use without rights Taxpayer Identification Number or Inauguration of a Taxable Entrepreneur;

c. do not submit SPT; 
d. submit SPT and / or information whose contents are incorrect or incomplete;

e. refuse to be examined according to Article 29 of the KUP Law;

f. show books, records, or other documents that are fake or falsified as if they were true, or did not represent the actual situation;

g. does not keep books or records in Indonesia, does not show or do not lend books, records or other documents;

h. do not keep books, records or documents which form the basis of accounting or other records and documents, including the results of data processing from books that are managed electronically or held online by application programs in Indonesia in accordance with Article 28 paragraph (11) of the KUP Law; or

i. not deposit taxes that have been deducted or collected.

so that it can cause a loss in state income, which is sentenced to a maximum of 6 (six) months imprisonment and a maximum of 6 (six) years and a fine of at least 2 (two) times the amount of tax payable which is unpaid or underpaid and a maximum of 4 (four) times the amount of unpaid or underpaid tax payable.

In this act or action it also includes any person who intentionally did not register, misused or used without the right of the Taxpayer Identification Number, or misused or used without the inauguration rights of the Taxable Entrepreneur. The aforementioned provisions also apply to representatives, power of attorney, employees of taxpayers, or other parties who order to do, who participate in committing, who advocate or who assist in committing criminal acts in the taxation field. (Article 43 paragraph (1) of Law Number 28 Year 2007) If WP is declared intentionally repeating or committing acts that are classified as criminal acts in the taxation field before the passing of 1 (one) year, starting from the completion of serving the prison sentence imposed, the WP is subject to heavier criminal sanctions, which are added 1 (one) time to 2 (two) times the previous criminal sanctions. (Article 39 paragraph (2) of Law Number 28 Year 2007) Sanctions imposed if WP submits application for temporary restitution of the SPT that is submitted is incorrect or incomplete(Article 39 paragraph (3) of Law Number 28 Year 2007) "Anyone who tries to commit a crime of abusing or using without the right a Taxpayer Identification Number or Inauguration of a Taxable Entrepreneur, or submits a tax return and / or information whose contents are incorrect or incomplete, in the context of applying for restitution or tax compensation or tax crediting, shall be punished with imprisonment for a minimum of 6 (six) months and a maximum of 2 (two) years and a fine of at least 2 (two) times the amount of restitution being applied for and / or compensation or credit done and at most 4 (four) times the amount of restitution requested and / or compensation or credit made. "

\section{Expiration of Prosecution (Article 40 of Law Number 28 Year 2007)}

Criminal acts in the field of taxation cannot be prosecuted after the past 10 (ten) years from the time the tax becomes due, the end of the Tax Period, the end of the Tax Year, or the end of the relevant Tax Year. This is intended to provide legal certainty for taxpayers, public prosecutors and judges. The period of 10 (ten) years is to adjust to the expiration of the storage of tax documents which are used as the basis for calculating the amount of tax owed, for 10 (ten) years.

\section{Sanctions for Officials (Article 41 of Law Number 28 Year 2007)}

Sanctions that can be imposed on officials who violate the prohibition of disclosing the confidentiality of taxpayers can be threatened with criminal sanctions as follows:

a. Because of negligence, a sentence of up to 1 (one) year imprisonment and a maximum fine of Rp. 25,000,000.00 (twenty-five million rupiah).To guarantee that confidentiality regarding taxation will not be notified to other parties and so that taxpayers in providing data and information will not hesitate, in the framework of implementing the Taxation Law, criminal sanctions are needed for the official concerned that causes disclosure of the confidentiality. Disclosure of confidentiality is done because negligence in the sense of neglect, carelessness, or lack of respect so that the obligation to keep the information or evidence that is on the Taxpayers protected by the Taxation Law is violated. For the negligence, the offender was sentenced to the appropriate punishment.

b. Because of intent, sentenced to a maximum imprisonment of 2 (two) years and a maximum fine of Rp 50,000,000.00 (fifty million rupiah). Acts or actions carried out intentionally are subjected to more severe sanctions compared to acts or actions taken due to negligence so that the officials concerned are more careful not to commit acts of divulging taxpayers' secrets. This provision also applies to someone who does not fulfil the obligations of the official. Prosecution of the criminal acts referred to above is only carried out on complaints of people whose confidentiality has been violated.

\section{Sanctions for Other Parties (Article 41A, Article 41B, Article 41C and Article 43 of Law Number 28 Year 2007)}

Other parties that may be subject to tax criminal sanctions:

a. $\quad$ every person who is obliged to provide the requested information or evidence as referred to in Article 35 of the KUP Law but intentionally fails to provide information or evidence, or provides information or evidence that is not properly sentenced to a maximum imprisonment of 1 (one) year and a maximum fine of Rp. 25,000,000.00 (twenty-five million rupiah). (Article 41A of Law Number 28 Year 2007) This provision also applies to other parties who order to do, who participate to do, who advocate or who help commit criminal acts in the field of taxation. (Article 43 paragraph (2) of Law Number 28 Year 2007)

b. every person who intentionally obstructs or complicates the investigation of criminal acts in the field of taxation shall be sentenced to a maximum imprisonment of 3 (three) years and a maximum fine of Rp. 75,000,000.00 (seventy-five million rupiah). (Article 41B of Law Number 28 Year 2007) This provision also applies to other parties who order to do, who 
participate to do, who advocate or who help commit criminal acts in the taxation field. (Article 43 paragraph (2) of Law Number 28 Year 2007)

c. every person who intentionally fails to fulfil the obligations referred to in Article 35A paragraph (1) of the KUP Law shall be liable to a maximum imprisonment of 1 (one) year or a maximum fine of Rp 1,000,000,000.00 (one billion rupiah). (Article 41C paragraph (1) of Law Number 28 Year 2007)

d. everyone who intentionally causes the fulfilment of the obligations of officials and other parties as referred to in Article $35 \mathrm{~A}$ paragraph (1) of the KUP Law shall be liable to a maximum imprisonment of 10 (ten) months or a maximum fine of Rp. $800,000,000.00$ (eight hundred million rupiahs). (Article 41C paragraph (2) of Law Number 28 Year 2007)

e. $\quad$ everyone who intentionally fails to provide data and information requested by the Director General of Taxes as referred to in Article 35A paragraph (2) of the KUP Law shall be liable to a maximum imprisonment of 10 (ten) months or a maximum fine of Rp. 800,000,000.00 (eight hundred million rupiah). (Article 41C paragraph (3) of Law Number 28 Year 2007)

f. every person who intentionally misuses taxation data and information that causes losses to the state shall be sentenced to a maximum imprisonment of 1 (one) year or a maximum fine of Rp. 500,000,000.00 (five hundred million rupiah). (Article 41C paragraph (4) of Law Number 28 Year 2007)

\section{Preliminary Evidence Check}

Examination is a series of activities to collect and process data, information, and / or evidence that is carried out objectively and professionally based on an inspection standard to test compliance with tax obligations and / or for other purposes in the context of implementing the provisions of tax legislation.

Preliminary Evidence is a condition, deed, and / or evidence in the form of information, writing, or objects that can provide a clue that there is a strong allegation that a Tax Crime is being done or has been committed by anyone who can cause a loss in state income.

Preliminary Evidence Check is an examination carried out to obtain Preliminary Evidence regarding an alleged Tax Crime has occurred.

The Director General of Taxes has the authority to conduct Initial Evidence Checks based on Information, Data, Reports and Complaints. Complaint is a notification accompanied by a request by an interested party to an authorized official to act according to the law of an individual or entity who has committed a Criminal Act in the Field of Taxation which has caused a loss.

The scope of the Preliminary Evidence Examination is the alleged occurrence of a Criminal Event specified in the Preliminary Evidence Examination Order. A Letter of Preliminary Evidence Check is the basis for conducting the Preliminary Evidence Check by the Preliminary Evidence checking team.

Type of Preliminary Evidence Check consists of:

1. Open Proof of Examination

An open Evidence Check is conducted in the case of:

a. Initial Evidence Checks related to requests for returning tax overpayments as referred to in Article 17B of the KUP Law; or

b. The Initial Evidence Check is a follow-up to the Examination to test compliance with tax obligations, the Initial Evidence Check is openly carried out with a written notification regarding the Initial Evidence Check to an individual or entity that is conducted the Initial Evidence Check.

2. Examination of the Preliminary Evidence is closed

Examination Preliminary Evidence is conducted privately without notification of the Examination of the Preliminary Evidence to an individual or entity who carried out the Preliminary Evidence Examination. Examination of the Preliminary Evidence is openly carried out within a period of not later than 12 (twelve) months from the date of submission of the Notification of Preliminary Evidence notification letter up to the date of the Preliminary Evidence Inspection Report. Examination of the Preliminary Evidence is carried out in a maximum period of 12 (twelve) months from the date of the Preliminary Evidence Inspection Order received by the Preliminary Evidence Inspector until the date of the Preliminary Evidence Inspection Report. Preliminary evidence. The Head of the Executing Unit for the Preliminary Evidence Audit can provide an extension of the period referred to in paragraph (3) no later than 24 (twenty four) months from the end of the specified period. Taking into account and taking into account the expiration of taxation, the expiration of prosecution in Taxation, and other considerations.

The Preliminary Evidence Check must be carried out in accordance with:

1. general standard for Preliminary Evidence Examination;

2. the standard implementation of the Preliminary Evidence Audit; and

3. Preliminary Evidence Check reporting standards.

General Standards for Preliminary Evidence Examination, namely Preliminary Evidence Examination carried out by Civil Servant Investigators within the Directorate General of Taxation who:

1. given the task, authority, and responsibility by the Head of the Executing Evidence Examination Unit to carry out the Preliminary Evidence Examination; 
2. get sufficient technical education and training as a preliminary evidence checker;

3. use his skills carefully and thoroughly;

4. is honest, free from despicable actions, and always prioritizes the interests of the state; and5. obey the provisions of the legislation in the field of taxation.

The standard implementation of the Preliminary Evidence Audit is regulated with the following conditions:

1. Carried out by a team of Preliminary Evidence examiners;

2. Supervised by the head of the Executing Evidence Examination Unit;

3. Preceded by good preparation;4. implemented in the office of the Directorate General of Taxes and / or other places deemed necessary by the Preliminary Evidence examiner;5. implemented within a certain period;6. documented in the Preliminary Evidence Check Paper; and7. obtained conclusions based on valid and sufficient Evidence.

The Standard for Proofing Examination reporting standards is governed by the following conditions:

1. The Preliminary Evidence Check report is prepared based on the Preliminary Evidence Check Working Paper; and

2. The Preliminary Evidence Audit report discloses the implementation, conclusions, and follow-up recommendations for the Preliminary Evidence Audit.

Preliminary Evidence Checker must:

1. Submit a letter of notification of the Preliminary Evidence Audit to an individual or entity carried out the Preliminary Evidence Inspection, if the Preliminary Evidence Examination is conducted openly;

2. Show the identity card of the Preliminary Evidence examiner, if requested by an individual or body carried out the Initial Evidence Check;

3. Show a Preliminary Evidence Audit Warrant or a Change Evidence Initial Investigation Order, if requested by an individual or entity who has carried out the Preliminary Evidence Check;

4. Returning evidence that has been obtained through borrowing and is not needed in the investigation process;

5. Conceal to other parties who are not entitled to everything that is known or notified to him in the framework of the Preliminary Evidence Check; and

6. Securing the Evidence Found in the Preliminary Evidence Check.

An individual or body that is carried out with Open Preliminary Examination, must:

1. to give an opportunity to the Preliminary Evidence examiner to enter and / or inspect the place or space, movable and / or immovable property that is suspected or reasonably suspected of being used to store the Evidence;

2. provide an opportunity for the Preliminary Evidence examiner to access and / or download data managed electronically;

3. show and / or lend Evidence to the Preliminary Evidence examiner;

4. provide verbal and / or written information to the Preliminary Evidence examiner; and

5. provide assistance to the Preliminary Evidence examiner in order to facilitate the Preliminary Evidence Examination.

A related party or third party that has a relationship with an individual or entity undertaken by the Preliminary Evidence Check is obliged to provide the information and / or evidence requested by the Preliminary Evidence examiner. An individual or body that is carried out with Open Preliminary Examination has the right to ask the Preliminary Evidence examiner to:

1. submit notification letter for the Preliminary Evidence Audit;

2. 2. show the identity card of the Preliminary Evidence examiner;

3. 3. show a Proof of Initial Proof of Examination or Proof of Initial Proof of Change; and returning evidence that has been borrowed and is not needed in the investigation process.

Preliminary Evidence Checker is authorized:

1. Enter and / or inspect the place, space, and / or goods that are suspected or reasonably suspected of being used to store evidence;

2. access and / or download data managed electronically;

3. borrow and / or examine Evidence;

4. Sealing certain places or spaces as well as movable and / or immovable property;

5. request information from related parties;

6. ask for information and / or evidence that is suspected to be able to give instructions on Criminal Acts in the Field of Taxation to third parties who have a relationship with an individual or entity;

7. requesting assistance from other parties in connection with their expertise in the context of carrying out the Preliminary Evidence Audit; and8. take other actions needed in the framework of the Preliminary Evidence Examination.

\section{Investigation Basis (Article 1 number (31) of Law Number 28 Year 2007)}

Investigation of criminal acts in the taxation field is a series of actions carried out by investigators to search for and collect evidence which with evidence makes the light of criminal acts in the taxation field occur and find the suspect. Investigators are certain 
Civil Servants in the Directorate General of Tax environment who are given special authority as investigators to conduct criminal investigations in the field of taxation in accordance with statutory provisions. Certain Civil Servants in the Directorate General of Tax environment who are appointed as investigators of criminal acts in the field of taxation by the authorized officials are investigators of criminal acts in the field of taxation. Criminal investigations in the field of taxation are carried out according to the provisions stipulated in the applicable Criminal Procedure Act. Investigation is a process of continuation of the examination results which indicate the beginning of evidence of tax crime. Taxpayers (WP) suspected of committing criminal offenses in the field of taxation cannot be directly investigated but must first be observed or examined. If based on observations or examinations found indications of criminal acts in the field of taxation, the Preliminary Evidence Check is conducted. If the results of the Preliminary Evidence Examination indicate that there is evidence of preliminary criminal acts in the taxation field, then it is proposed to be followed up with an investigation. (Article 43A paragraph (1) of Law Number 28 Year 2007)

\section{Duties and Authorities of the Investigator}

The task of the investigator (Article 1 number (31) of Law Number 28 of 2007)The task of the Investigator is to search for and collect evidence which makes the light of criminal acts in the taxation field occur and find the suspect. Authority of the investigator (Article 44 of Law Number 28 Year 2007) The authority of the Investigator is:

a. receive, seek, collect, and examine information or reports relating to criminal acts in the taxation field so that the information or report becomes more complete and clear;

b. examine, search for and collect information about individuals or entities concerning the truth of acts committed in connection with criminal acts in the taxation field;

c. request information and evidence from individuals or entities in connection with criminal acts in the field of taxation;

d. examine books, records and other documents relating to criminal acts in the taxation field;

e. conduct a search to obtain evidence of books, records and other documents, and confiscate said evidence;

f. requesting assistance from experts in the context of carrying out the task of investigating criminal offenses in the taxation field;

g. order to stop and / or prohibit someone from leaving the room or place while the inspection is taking place and checking the identity of the person, object, and / or document being carried;

h. photographing someone related to criminal acts in the field of taxation;

i. summon people to hear their statements and examine them as suspects or witnesses;

j. stop the investigation; and / take other actions necessary to smooth the investigation of criminal acts in the field of taxation according to the provisions of the legislation.

The authority mentioned above includes confiscation. The confiscation can be carried out, both for movable and immovable property, including bank accounts, receivables, and securities of taxpayers, tax bearers, and / or other parties that have been designated as suspects. In addition to protecting the evidence found in the investigation process, the Tax Investigator is authorized to carry out sealing actions in accordance with the provisions of the applicable tax legislation. In the context of carrying out the authority of the investigation referred to above, the investigator may request the assistance of other law enforcement officers. The investigator notifies the commencement of the investigation and submits the results of his investigation to the public prosecutor through the investigator of the Republic of Indonesia National Police official in accordance with the provisions stipulated in the Criminal Procedure Act.

\section{Termination of Investigation (Article 44A and Article 44B of Law Number 28 Year 2007)}

The investigation can be stopped in the event of:

a. there is not enough evidence;

b. the incident did not constitute a criminal offense in the taxation field;

c. the investigation was stopped because the event had expired, or

d. the suspect died.

In the event that an investigation of a criminal offense in the field of taxation is terminated unless the event has expired, a tax assessment letter can still be issued. In addition, in the interest of state revenue, at the request of the Minister of Finance, the Attorney General can stop investigating criminal acts in the field of taxation no later than 6 (six) months from the date of the request letter. Termination of investigation of criminal acts in the field of taxation as referred to above is only carried out after the Taxpayer has paid tax debt that is not or underpaid or that should not be returned and is supplemented with administrative sanctions in the form of 4 (four) times the amount of tax that is not or underpaid, or that should not be returned.

\section{B. ULTIMUM REMEDIUM OR PREMUM REMEDIUM IN THE ENFORCEMENT OF TAX LAW}

Related to the Ultimum Remedium Or Premum Remidium Aspect, if we look at the provisions of tax legislation related to the Law Enforcement Process by the Directorate General of Taxes in accordance with Law Number 28 of 2007 concerning General Provisions and Taxation procedures, it can be concluded that the Directorate General of Taxes Has Very extensive discourse related to 
the Criminal Process in Taxation Violations, In the Meaning of the Directorate General of Taxation Subjectively Allow When to Use the Instrument of Criminal Sanctions or Administrative Sanctions.

Conditions That Enable These Subjectivities can be seen from the Process of Beginning Evidence Inspection derived from Data, Information, Reports and Complaints (IDLP). Data Processing, Information, Reports and Complaints Completely are the authority of the Directorate General of Taxes. From the results of the IDLP Processing, the Directorate General of Taxes has the full discretion to choose to use Administrative Sanctions or Criminal Sanctions related to the results of IDLP Processing which can harm the country's Finances by Taxpayers.

Even though the Taxpayer still has the right to disclose his actions, there is no clear parameter for the results of the disclosure by the taxpayer with the calculation from the Directorate General of Tax Investigators, so there is legal uncertainty related to the disclosure of the untruth done by the taxpayer. Assembled by Article 44b, where the Attorney General Can Stop the Investigation Process of the Minister of Finance's Proposal if the Taxpayer conducted an Investigation to Pay Taxpayers Add 400\% Sanctions, This Provision also does not provide certainty, because in that article there are the words "Can", so it is a creation of the Attorney General to stop the investigation.

Related to Ultimum Remedium in Tax Criminal Acts if Observed Corporate Penalty Sanctions that will be applied are Minimum and Maximum penalties, this condition is less precise if it is considered the ultimum Remedium principle must be applied.

As a result of the above reasons it is very clear if the Tax Criminal Enforcement does not always always apply the Ultimum Remedium Principle but is more inclined to Premum Remidium, this condition is not appropriate if we use a comparison of criminal enforcement in taxation in other countries such as the Netherlands, Germany, and Other European Countries.

\section{CONCLUSION}

Based on the results of the research and analysis of the subject matter discussion, the following conclusions from the answers to the problems in this study, namely

1. Tax Criminal Law Arrangement based on Law Number 28 Year 2007 regarding General Provisions and Tax Procedures along with the Implementing Regulations. These Regulations have been in place since 2008 so there is a need for changes, especially related to the era of Information technology in Business transactions

2. The application of Ultimum Remedium in Taxation Crimes in Indonesia does not provide a legal certainty for taxpayers, because the regulation instrument has uncertainty in its application whether to use the Ultimum Remedium Principle or Premum Remedium, this is because the Directorate General of tax has a very broad authority related to granting Criminal sanctions or administrative sanctions.

[1] Ali, Achmad, Menguak Teori Hukum dan Teori Peradilan: Vol. 1, Kencana, Jakarta, 2013.

[2] Asshiddiqie, Jimly dan M. Ali Safaat, Teori Hans Kelsen: Tentang Hukum, Sekretariat Jenderal dan Kepaniteraan Mahkamah Konstitusi RI, Jakarta, 2006. --, Pokok-Pokok Hukum Tata Negara Indonesia, BIP, Jakarta, 2007.

[3] Azhary,M. Tahir, Negara Hukum, Bulan Bintang, Jakarta, 1992.

[4] Effendi, Lutfi, Pokok-pokok Hukum Administrasi, Edisi pertama Cetakan kedua, Bayumedia Publishing, Surabaya, 2004.

[5] Erwin, Muhammad, Filsafat Hukum, Raja Grafindo, Jakarta, 2012.

[6] Fuller, Lon L., The Morality of Law, Yale University Press, New Haven and London, 1969.

[7] Hadjon, Philipus M., Perlindungan Hukum Bagi Rakyat di Indonesia, Peradaban, Surabaya, 2007. -, Pengantar Hukum Administrasi Indonesia, Cetakan ketujuh Gadjah Mada University Press, Yogyakarta, 2001.

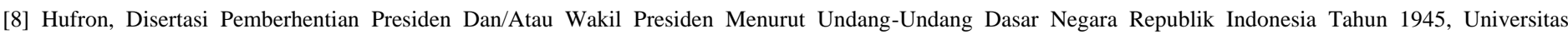
Brawijaya, Malang, 2012.

[9] Huijbers, Theo, Filsafat Hukum, Kanisius, Yogyakarta, 1995.

[10] Ibrahim, Johny, Teori \& Metodologi Penelitian Normatif, Bayumedia Publishing, Surabaya, 2006.

[11] Marbun, SF. dkk, Dimensi-Dimensi Pemikiran Hukum Administrasi Negara, UII Press, Yogyakarta, 2001.

[12] Marzuki, Peter Mahmud, Pengantar Ilmu Hukum, Kencana, Jakarta, 2008.

[13] Mertokusumo, Sudikno. 2006. Penemuan Hukum Sebuah Pengantar. Yogyakarta: Liberty.

[14] Prodjodikoro, Wirjono. 2003. Asas-Asas Hukum Pidana di Indonesia. Bandung: Refika Aditama.

[15] Winarta, Frans Hendra. 2012. Hukum Penyelesaian Sengketa. Jakarta: Sinar Grafika.

\section{AUTHORS}

First Author - Lucky kartanto, Lecturer at Accounting Programs, at Faculty of Economics And Business, Widya Kartika University, Surabaya, East Java, Indonesia, vinluck2002@yahoo.com

Second Author - Prasetijo Rijadi, Lecturer at Undergradutae and Master Programs, at Faculty of Law, Bhayangkara University, Surabaya, East Java, Indonesia kaplucky@gmail.com.

Third Author - Sri Priyati, Lecturer at Undergradutae Programs, at Faculty of Law, Bhayangkara University, Surabaya, East Java, Indonesia vinluck2002@yahoo.com.

Correspondence Author - Lucky Kartanto, vinluck2002@yahoo.com, (+6281330104150). 
International Journal of Scientific and Research Publications, Volume 10, Issue 3, March 2020

ISSN 2250-3153 